\title{
Observations on Plasma Ammonia in Patients with Leukemia
}

High blood ammonia levels in patients with leukemia have been described by FULD in $1933^{1}$; recently LARSEN and MANNING ${ }^{2,3}$ and BOCKEL, IMLER and STAHL confirmed an increased ammonia content of venous blood in patients with leukemia.

LARSEN and MANNING suggested that high blood ammonia results from in vitro metabolic activity of the large circulating leucocyte mass with output of ammonium ions from the leukemic cells after blood collection ${ }^{2,3}$.

Bockel, IMLER and Stahl confirmed the cell's source

Table I.

\begin{tabular}{llll}
\hline Normal subjects & 20 & mean 14.20 & S.D. \pm 3.74 \\
Leukemic patients & 30 & mean 47.13 & S.D. \pm 20.54
\end{tabular}

Analysis of variance

\begin{tabular}{lcccc}
\hline $\begin{array}{l}\text { Source of } \\
\text { variation }\end{array}$ & $\begin{array}{l}\text { Degrees of } \\
\text { freedom }\end{array}$ & $\begin{array}{l}\text { Sum of } \\
\text { squares }\end{array}$ & $\begin{array}{l}\text { Mean } \\
\text { squares }\end{array}$ & $\begin{array}{l}\text { Variance } \\
\text { ratio }\end{array}$ \\
\hline Between groups & 1 & 13014 & 13014 & $\begin{array}{l}\mathrm{F}=49.86 \\
P<0.01\end{array}$ \\
Within groups & 48 & 12544 & 261 & \\
Total & 49 & 25558 & & \\
\hline
\end{tabular}

Table II.

\begin{tabular}{llrl}
\hline Diagnosis & Patient & WBC & $\begin{array}{l}\text { Arterial } \\
\text { ammonia }(\gamma \%)\end{array}$ \\
& & & \\
\hline Myelogenous leukemia & L.D. & 66,400 & 40 \\
& U.R. & 72,000 & 46 \\
& V.A. & 12,200 & 20 \\
& E.G. & 8,600 & 22 \\
& M.P. & 22,000 & 25 \\
& R.Z. & 48,400 & 45 \\
& M.M. & 36,000 & 40 \\
& L.T. & 74,000 & 53 \\
& M.V. & 40,000 & 43 \\
& L.M. & 96,000 & 80 \\
& T.A. & 38,000 & 35 \\
& G.N. & 18,000 & 25 \\
& R.R. & 28,000 & 38 \\
& N.B. & 56,000 & 45 \\
& L.T. & 48,000 & 55 \\
& E.G. & 37,600 & 40 \\
& F.B. & 57,900 & 60 \\
& S.C. & 83,000 & 72 \\
& A.V. & 19,600 & 28 \\
& Z.I. & 61,000 & 55 \\
& & & \\
& A.C. & 102,000 & 96 \\
Lymphatic leukemia & 28,000 & 24 \\
& U.V. & 46,800 & 25 \\
& N.L. & 34,000 & 45 \\
& G.T. & 54,000 & 47 \\
& R.E. & 41,800 & 32 \\
& F.D. & 70,000 & 66 \\
& C.B. & 30,400 & 47 \\
& E.V. & 56,000 & 65 \\
S.F. & V.L. & 82,000 & 100 \\
\hline
\end{tabular}

of ammonium ions but stated that the phenomenon is present in vivo ${ }^{4}$.

We have therefore studied the arterial plasma ammonia levels in a caselist of 20 normal subjects, 20 patients with chronic myelogenous leukemia, 6 with chronic lymphatic leukemia and 4 subjects with acute leukemia.

Methods. Blood was obtained from each patient and an aliquote immediately placed in an ice-tube, with heparin as anticoagulant: heparin, in fact, inhibits adenosine deaminase and consequently the production of ammonia from deamination of nitrogenous materials ${ }^{5-8}$.

Plasma was separated by centrifugation at $+4^{\circ} \mathrm{C}$. Ammonia was determined by a new method based on ion exchange resin as proposed by MrLLER and RICE ${ }^{9}$ and modified by SEcchi et al. ${ }^{10}$.

Results and discussion. The ammonia values and leucocyte counts are expressed in Tables $I$ and II. Plasma arterial ammonia levels are statistically increased in leukemic patients. In chronic leukemia a correlation was revealed between WBC counts and ammonia levels; in acute loukemia no correlation was observed.

The prompt refrigeration of blood samples and the ion exchange resin method which we adopted did not, in our opinion ${ }^{11}$, permit the occurrence of 'laboratory phenomenon' of ammonia production by an enzymatic process following the collection of blood. We cannot, however, exclude a possible cell lysis. No patient showed neurological symptomatology: in fact, in our caselist plasma ammonia levels did not reach the high values detectable in hepatic pre-coma and coma ${ }^{12}$.

Riassunto. In una casistica di 50 pazienti affetti da leucemia acuta e cronica sono stati riscontrati elevati livelli dell'ammoniaca arteriosa plasmatica. Viene discussa l'origine degli ammonio-ioni presenti nel plasma.

\section{A. Rezzonico, N. Gervasini and G. C. Secchi ${ }^{13}$}

Istituto di Clinica Medica Generale e Terapia

Medica della Università di Milano (Italy), 13 March 1967.

1 H. FuLv, Klin. Wschr, 35, 1364 (1933),

2 R. T. Manning and W. E. Larsen, J. Lab. clin. Med. 56, 925 (1960).

3 W. E. Larsen and R. T. Manning, J. Kans, med. Soc. 7, 302 (1961).

4 R. Bockel, M. Imler and J. Stahl, Strasb, med, 15, 309 (1964).

$5 \mathrm{~J}$. De Groote and J. Vanderbroucke, Am. J. dig. Dis. 3, 502 (1958).

J. A. Jacouez, R. JeLtsch and M. J. Hood, J. Lab. clin. Med. 53, 942 (1949).

7 H. O. Conn and A. A. Kulgan, J. Lab. clin. Med. 63, 1033 (1964).

E. S. Dimond, J. Lab. clin. Med. 46, 807 (1955).

G. E. Miller and S. D. Rice, Ain. J. clin. Path. 39,97 (1963).

10 G. C. Secchi, A. Rezzonico and A. Cocchr. Clinica chim, Acta 12, 235 (1965).

11 I. Provini and G. C. Secchr, Diagnosi, Napoli 19, 289, 1963.

12 G. C. Secchi, A. Rezzonico, N. Gervastnr and A. Cocchi, Atti XVI Congr. Naz, Soc, ital. Gastroenterol (Cappelli, Bologna 1965), p. 1019.

13 Present address: Clinica del Lavoro dell'Universita di Milano (Italy). 